\title{
Dr. Hari Man Shrestha Speech during HYDRO Nepal Excellence Awards 2073 Distribution Ceremony
}

$\mathrm{D}$

istinguished Participants,

At the outset, I would like to thank Hydro Nepal, the organizer of this event, for honoring and felicitating me with the prestigious Life Time Achievement Award.

Allow me to start with a glimpse of my career. Nearly fifty five years ago, I got a chance to get engaged in the design of Panauti Hydropower Project. I was at the verge of completing my engineering study at that time. In $1963 \mathrm{AD}$, I played a vital role in the construction of the same hydropower station. The plant came into operation in $1965 \mathrm{AD}$. The good news is although the stipulated design life of the project is about to finish, but I am still alive.

In this fifty-fiveyears long journey in Nepal's water resources and hydroelectricity years of my tenure in the Government. Even after the Government Service, I am still

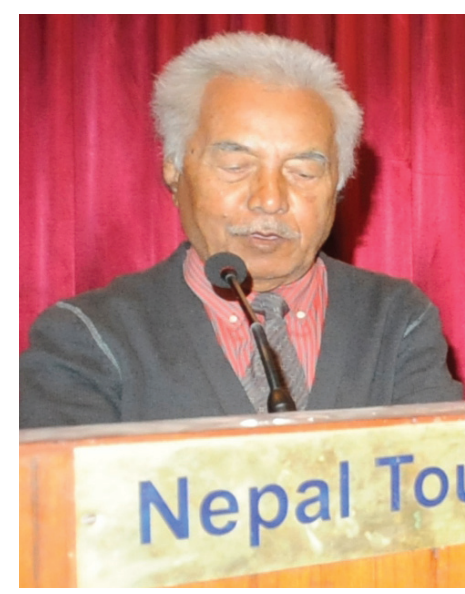

sector, I spent thirty-three engaged in the sector. During this whole period, I have devoted towards progress and prosperity of water resources and hydroelectricity in Nepal and I have tried my best to put efforts in the sector.

The findings of my Ph.D. dissertation clearly depicted the fact that water resources and hydroelectricity are the only known major natural resources in Nepal. Thus my attention was drawn towards proper and sustainable use of these resources for the welfare of our nation.

I firmly believe that I fall on the category of individuals who strongly believe on the principles of learning by doing and utilization of own resources, means and skills to fulfill the required needs. I did not believe that you would prosper by exporting electricity to India through the large scale hydro projects which were beyond our reach. Few of such projects studied that time lied in Lower Karnali Basin. Since then, even in the capacity of a bureaucrat I started to advocate on the establishment of projects which would generate the power that would be appropriate for Nepali market and serve as a catalyst to develop the sector further.

In this discourse and in the capacity of a Nepali Citizen, I always pondered and referred to few points namely: focus on the study and research they would bring tangible benefits to Nepal, public disclosure of the facts and figures is mandatory, creating Government's awareness through working papers and putting a caution note on the issues which would bring negative externalities. I spent my time on identifying the feasible projects and surveying them, developing master plans, determining the priority of execution of projects based on the needs and lucrative attributes.

In context of aforementioned activities, around hundred publications were made in forms of documents, proposals, approach papers, research papers, policy papers and interviews in various languages. Along with this, to create a base for the authentic study and the institutional development of water resources and hydroelectricity, Water and Energy Commission Secretariat (WECS) was established. However, it took five years to establish the secretariat office. In order to give a height to WECS and make it the centre of excellence, I spent nearly seventeen years of my career.

In a nutshell, if I have to spell out the lessons I have learned and challenges I have faced during my fifty five years of study, investigations and professional engagement on water resources and the hydroelectricity sector, I would like to point out to a few treaties and ratifications signed by the authorities of Nepal Government, which I think would have long term negative repercussions to the nation.

For example:

a. In the time of British India:

- the then rulers agreed to construct Jamuwar, Eiswa and Marthi impoundments which led the flooding in Nepali territories.

- For constructing the Sharada Canal and Banbasa Barrage, lands were exchanged such that the sites lied on the Indian territory.

b. After the liberation of India:

- Through the Koshi and Gandak Agreement and Mahakali Treaty, which was signed two decades ago, people are deprived of the rights of water, particularly by Gandak and Mahakali. Similarly, due to the Koshi Barrage, the local areas have become the victims of floods and the embankment erosion.

c. In the recent visit of Indian Prime Minister Narendra Modi to Kathmandu, the PDA of Upper Karnali and ArunIII, which was very lucrative for Nepal and had an attractive chance of investment and utilization within Nepal, has 
been handed over to Indian companies.

Besides all these treaties and agreements, different ongoing projects, which were very favorable, were disallowed to complete. For example, in 1980s, although 225 MW Sapta-Gandaki Project was in the stage of construction by the financial aids of Japanese Government along with 275 ton/day capacity Urea Fertilizer Plant by utilization of surplus monsoon energy, Arun III project was brought into the picture. Arun III had no access roads and no completed feasibility study at that time, and without having knowledge of the influence of the World Bank, decision was taken against the implementation of Sapta Gandaki project and hence the nation was compelled to import power from India in high quantity to get rid of power cuts. The country lost the opportunity of self sufficiency in Urea fertilizer. This development also had further repercussion, the World Bank nearly banned Kali Gandaki A which was supposed to be implemented by the public sector. Despite such difficulties and background, the contribution of Mr. Wark, the then Resident Representative of UNDP, ADB, Government of Japan, the then Secretary Mr. Bhubanesh Kumar Pradhan along with Project Chief Dr. Niranjan Kapali to bring the Kali Gandaki-A project to implementation phase is praiseworthy.

I firmly believe that the above suicidal activities will eventually result in situations where our future generations may have to purchase water flowing within our territory and electricity produced in India or other foreign countries at a high price. Being a Nepalese Citizen, I am anxious towards this intolerable condition.

In this auspicious occasion, I would like to recall and appreciate individuals who were my sources of inspiration and motivation toward my journey in the field of water resources and hydroelectricity in Nepal:

- First of all, my Russian teacher Pohper Amaro VINCH.

- The then late King Birendra who believed on my ideas and supported my opinion and the proposal. He convinced the then ministers, secres stary, departmental chief and other engineers who were against idea of the implementation of Kulekhani reservoir project.

- Ministers: DP Adhikari, Harishchandra Mahat and Padam B. Khatri

- Secretaries: Achut B. Rajbhandari. Madhu Shudhan Dhakal and Bhubanesh Kumar Pradhan

- Engineers: Nanda Kishor Agrawal with Rameshwor Man Amatya

- Editors: Shyam Shrestha and Rajendra Dahal

- Social Scientist: Bihari Krishna Shrestha

These individuals are always in my heart who contributed substantially for the betterment of our beloved motherland.

Last but not the least, at this juncture of my setting life (I will be 84 soon), I am grateful to Hydro Nepal Journal and its family for providing a space to my contemporary articles on the field of water resources and hydroelectricity and publishing them.

Thank you.

(The above speech was delivered by Dr. Hari Man Shrestha during the HYDRO Nepal Awards Distribution Ceremony held on Chaitra 31, 2073 (April 13, 2017) in Kathmandu, Nepal. Dr. Shrestha has died at the age of 83 on April 27, 2017. We offer our tribute to the departed soul. Editor) 